\title{
'Low sodium' diuresis and ileal loss in patients with ileostomies: effect of desmopressin
}

\author{
M Sutters, D J S Carmichael, R J Unwin, C Sozi, M Hunter, J Calam, S L Lightman, \\ W S Peart
}

\begin{abstract}
Patients with ileostomies show an early diuresis when sodium restricted; this, together with an obligatory ileal sodium loss, predisposes them to severe salt and water depletion. The role of arginine vasopressin in this circumstance and whether it is natriuretic, or antinatriuretic, is unclear. There is also controversy over its likely effect on small bowel fluid reabsorption. We have examined the effect of the non-pressor $\left(V_{2}\right)$ synthetic vasopressin analogue 1-deamino-8-D-arginine (desmopressin) on renal and ileal sodium and water excretion in ileostomy patients during acute adaptation to a low sodium diet. Patients were studied on two separate occasions (nonrandomised) with and without the administration of desmopressin $(0.75 \mu \mathrm{g}$ intramuscular, three times a day). In eight subjects without desmopressin there was pronounced diuresis on the first low sodium day, associated with a fall in renal sodium excretion and no change in ileal output or composition. In five (of the original) subjects with desmopressin there was pronounced antidiuresis, no change in renal sodium excretion, and no change in ileal output or composition. In both studies rises in plasma renin activity and salivary aldosterone concentration lagged behind the early decline in renal sodium excretion. We have confirmed the phenomenon of 'low sodium' diuresis after sodium restriction in ileostomy patients and shown that it can be prevented by desmopressin. Desmopressin has no direct or indirect effect on renal sodium excretion or ileal fluid and electrolyte loss in humans.
\end{abstract}

Medical Unit, St Mary's Hospital Medical School, London W2 1PG

M Sutters

D J S Carmichael

R J Unwin

C Sozi

M Hunter

W S Peart

Department of Gastroenterology,

Hammersmith Hospital, London W12 ONN

J Calam

Medical Unit, Charing Cross and Westminster Hospital Medical School, London SW1

S L Lightman

Correspondence to: R J Unwin, Department of Clinical Pharmacology Hammersmith Hospital, Du Cane Road, London W12 0NN.

Accepted for publication 3 August 1990
Patients with ileostomies are at greater risk of developing salt and water depletion because of a fixed ileal sodium and water loss. ${ }^{1}$ If dietary sodium intake falls these patients rapidly become dehydrated and hypovolaemic, despite normal renal function and adaptation. ${ }^{2}$ This can be an important clinical problem, patients commonly presenting with lethargy, postural hypotension, and in severe cases prerenal uraemia. ${ }^{3}$ Despite substantial sodium losses, normal plasma sodium concentration (and osmolality) is usually maintained because of a simultaneous water diuresis matching sodium and water deficits. ${ }^{4}$ The mechanism of this diuresis is uncertain but is presumed to entail a change in arginine vasopressin secretion, although in previous studies on these patients and in normal subjects no significant change in plasma arginine vasopressin concentration was found. ${ }^{246}$ Small changes in plasma arginine vasopressin concentration can produce large changes in urine volume, and it is possible that any decrease in plasma arginine vasopressin concentration may be too small to be detected, or that the kidney's sensitivity to circulating arginine vasopressin might alter under these conditions.

The importance of arginine vasopressin in the regulation of plasma osmolality and volume through its effect on renal water excretion is well established. ${ }^{78}$ This hormone may also affect the renal excretion of sodium: in animals and humans infusions of arginine vasopressin have been shown to increase sodium excretion..$^{911}$ This raises the possibility of a synergistic effect of arginine vasopressin on renal water and sodium excretion. A fall in arginine vasopressin secretion sufficient to cause diuresis may enhance the kidney's ability to conserve sodium; this might account in part for the close temporal relation between the onset of renal sodium retention and the 'low sodium' diuresis seen in ileostomy patients during sodium restriction. ${ }^{134}$

We have examined the effect of desmopressin, a selective $V_{2}$ (antidiuretic) vasopressin agonist with a long duration of action, on renal water and sodium excretion and ileal effluent during dietary sodium restriction in patients with ileostomies.

\section{Methods}

Eight patients with ileostomies (age range 50-70 years; five women, three men) were studied. All were well and taking no medication at the time of study. Each had undergone total colectomy as treatment for ulcerative colitis between 12 and 27 years previously. The study was approved by the Ethical Committee of St Mary's Hospital and the Ileostomy Association of Great Britain, and patients gave informed consent.

\section{PROTOCOL}

Patients were admitted to a ward for four days on two occasions (without and with desmopressin, order not randomised) separated by at least two months. During each four day period they received a low sodium (30 mmol/day) diet. Individual requirements of protein, calories, fat, and carbohydrates were assessed by a dietician and held constant throughout the study. Average daily intake was of $2125 \mathrm{kcal}, 90 \mathrm{mmol}$ potassium, $80 \mathrm{~g}$ protein, $70 \mathrm{~g}$ fat, and $240 \mathrm{~g}$ carbohydrate. Daily fluid intake and drinking pattern were held constant according to individual preference established on the first day. During the first three days (1-3), extra sodium was given with meals ( $\mathrm{NaCl}, 500 \mathrm{mg}$ capsules) to raise the daily intake to $250 \mathrm{mmol}$ (high sodium). The abrupt transition to a low sodium diet was achieved by omitting these capsules and reducing 
sodium intake to $30 \mathrm{mmol}$ on day 4 (low sodium). We have found in earlier studies that a pronounced fall in renal sodium excretion and an increase in urine flow rate occur within about 24 hours of dietary sodium restriction. ${ }^{42}$ The same protocol was followed in the desmopressin part of the study, which was carried out on five of the original eight patients: desmopressin (1deamino-8-D-arginine vasopressin, Ferring) was given by intramuscular injection $(0.75 \mu \mathrm{g}$ three times daily) on the low sodium day (day 4) at 0800,1500 , and 2200 hours. This dose is comparable with that used to control nocturnal polyuria in patients with autonomic failure and produces a moderate and sustained antidiuresis. ${ }^{13}$

Subjects were weighed at 0800 each day. Blood pressure was recorded lying at 1000 and 1830. After 30 minutes supine venous blood was sampled (via an indwelling Teflon cannula introduced into a forearm vein under lignocaine local anaesthesia) at 1000,1400 , and 1800 on days 3 (high sodium) and 4 (low sodium) for measurement of plasma renin activity, sodium, potassium, creatinine, total protein, and osmolality. Urine and ileal fluid were collected throughout each day; urine samples were stored at $-20^{\circ} \mathrm{C}$ until analysis for sodium, potassium, osmolality, creatinine, and arginine vasopressin concentration. Ileal effluent was homogenised in a Waring blender and ultracentrifuged, decanted, and the supernatant analysed for sodium and potassium concentration.

\section{LABORATORY ANALYSES}

Sodium and potassium concentrations in plasma, urine, and ileal fluid were measured by flame photometry (Corning model 430) and osmolality cryoscopically (Gonotec Osmomat 300). Creatinine in urine and plasma was measured colorimetrically, as creatinine alkaline picrate and total plasma protein by the Biuret method (Chemlab auto-analyser). Ileal effluent dry weight was measured from dessicated samples of the homogenised ileal effluent and electrolyte concentrations expressed in terms of ileal water. Plasma renin activity was measured by the radioimmunoassay of angiotensin I generated from endogenous substrate ${ }^{14}$; salivary aldosterone concentration was measured by radioimmunoassay. ${ }^{15}$ Urinary arginine vasopressin was measured by radioimmunoassay; high performance liquid chromatography data confirmed that the immunoreactive molecule coeluted with synthetic arginine vasopressin and bioassay studies in the ethanol anaesthetised and water loaded rat confirmed the biological activity of urinary arginine vasopressin. ${ }^{16}$ The cross reactivity of the arginine vasopressin assay with desmopressin in urine was $0.014 \%$ and the lowest detectable limit was $1 \cdot 25 \mathrm{pmol} / \mathrm{l}$ of urine. In samples from the control study calcium and phosphate were measured colorimetrically. ${ }^{17}$

\section{DATA ANALYSIS}

Data from the first two days of each study were excluded from the analysis as this was the time necessary to allow equilibration from individual differences in prestudy sodium intake. For each variable, comparison between observations on days 3 (last high sodium) and 4 (first low sodium) was made by two way analysis of variance and covariance (factors: subject, day; covariate: phase - control $v$ desmopressin); results are given as mean (SEM). Plasma renin activity, salivary aldosterone concentration, and renal arginine vasopressin excretion were found to be log normally distributed and their logarithms used in the statistical analysis; therefore, results are given as geometric mean (antilog of mean of logarithms) and $95 \%$ confidence intervals.

\section{Results}

\section{BLOOD PRESSURE AND BODY WEIGHT}

Supine arterial blood pressure did not change during sodium restriction and was unaffected by desmopressin: control 143 (12)/85 (4) to 139 (10)/81 (3) mmHg; desmopressin: 138 (9)/81 (2) to $141(12) / 83(5) \mathrm{mmHg}(\mathrm{p}>0 \cdot 1)$. Body weight fell slightly during the control study $(69 \cdot 3(7 \cdot 2)$ to $68.5(7.3) \mathrm{kg} ; \mathrm{p}=0.06)$, but there was little change during desmopressin administration $(73 \cdot 3(11 \cdot 2)$ to $72 \cdot 9(11 \cdot 3) \mathrm{kg} ; \mathrm{p}>0 \cdot 1)$.

\section{URINE}

In the control study urine flow rate increased significantly on day 4 (low sodium) and decreased during desmopressin administration; there were corresponding changes in urine osmolality (Fig 1). The falls in renal arginine vasopressin and sodium excretion on day 4 were unaffected by desmopressin administration (Fig 2). There was no change in creatinine clearance (not shown) or renal potassium excretion (control $3.03(0.27)$ to $3.14(0.26) \mathrm{mmol} / \mathrm{h}$; desmopressin $3.14(0.25)$ to $2 \cdot 68(0 \cdot 23) \mathrm{mmol} / \mathrm{h} ; \mathrm{p}>0 \cdot 1)$. In the control study renal phosphate excretion (a marker of proximal tubule sodium reabsorption) increased from 1.05 $(0.09)$ to $1.34(0 \cdot 10) \mathrm{mmol} / \mathrm{h} ; \mathrm{p}<0.05$.

\section{PLASMA AND SALIVA}

Table I summarises the changes in plasma composition and salivary aldosterone concentration. During the control study plasma osmolality fell initially and then recovered, but the plasma sodium concentration continued to fall and the plasma protein concentration increased. The plasma calcium concentration increased with total protein, but the plasma phosphate concen-

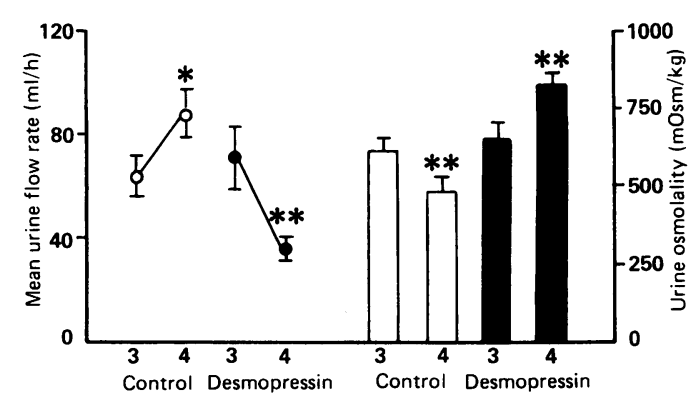

Figure 1: Changes in urine flow rate (left panel) and urine osmolality (right panel) after dietary sodium restriction, day 3 (high sodium) to day 4 (low sodium). ${ }^{\star} p<0.05,{ }^{\star}{ }^{\star} p<0.01$ compared with the corresponding value on day 3 . 


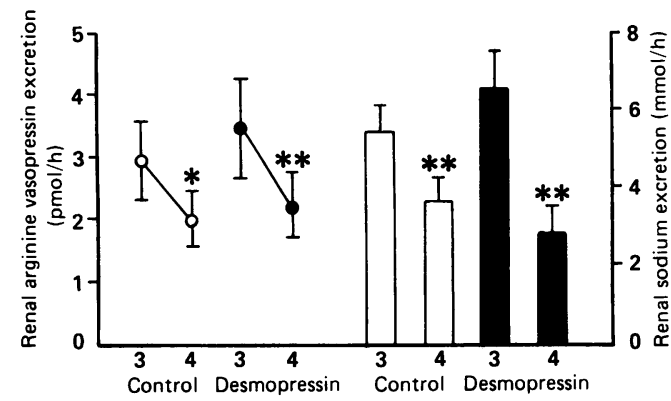

Figure 2: Changes in renal arginine vasopressin (left panel) and sodium (right panel) excretion after dietary sodium restriction, day 3 (high sodium) to day 4 (low sodium). $\star p<0.05, \star \star p<0.01$ compared with the corresponding value on day 3 .

tration did not change. Not surprisingly, during desmopressin administration there was a greater fall in plasma osmolality (no recovery) and sodium concentration and no increase in the plasma protein concentration. Plasma renin activity and salivary aldosterone concentration did not increase significantly on day 4 in either study, though there was a rise in the latter on day $4(p=0.09)$ of the desmopressin study; plasma renin activity had risen significantly by the morning of day 5 (second low sodium) in both studies. Desmopressin had no effect on plasma renin activity or salivary aldosterone concentration.

\section{ILEAL EFFLUENT}

Ileal water and electrolyte losses were unaffected by sodium restriction and desmopressin administration (Table II).

\section{Discussion}

The decline in renal sodium excretion after dietary sodium restriction was exponential, with a $t^{1 / 2}$ of about $50 \%$, the largest absolute fall occurring within the first 24 hours. ${ }^{18}$ Because of an obligatory ileal sodium loss of about 100 $\mathrm{mmol} /$ day (Table II) patients with ileostomies have an exaggerated renal response to sodium restriction compared with normal subjects and rapidly become sodium depleted. This is illustrated by the early and pronounced fall in plasma sodium concentration and osmolality (Table I). Comparing control with desmopressin administration, the fall in plasma osmolality seems to be corrected by the associated 'low sodium' diuresis (Table I and Fig 1); an appropriate response that maintains plasma osmolality in the face of solute (mainly sodium) depletion. If ileal diarrhoea becomes a cause of excessive sodium loss ileostomy patients will develop severe sodium and water depletion, in part because of a normal physiological response. A similar diuresis occurs in the sodium depleted rat, where regulation of plasma osmolality may depend on increased renal water excretion and also could entail altered renal sensitivity to arginine vasopressin. ${ }^{19}$ In the dog, thirst seems to be a major osmoregulator ${ }^{20}$; in humans drinking patterns tend to reflect habit and social activity. The mechanism of this early diuresis is not proved but is likely to result from a fall in arginine vasopressin secretion. Repeated studies in normal humans, ${ }^{56}$ in whom a low sodium' diuresis also occurs, ${ }^{12}$ and in ileostomy patients ${ }^{24}$ have failed to detect a change in plasma arginine vasopressin concentration. This is more likely to be due to insensitivity of measurement rather than to an intrinsic change in the kidney's response to arginine vasopressin (compare the rat), since the diuresis is readily reversed by modest doses of desmopressin.

Renal arginine vasopressin excretion was measured because it is believed to be a useful index of arginine vasopressin secretion, particularly when changes in plasma arginine vasopressin concentration are small or undetectable ${ }^{21-24}$; however, there is evidence that renal arginine vasopressin excretion may be affected by urine solute concentration or excretion rate. ${ }^{25} 26$ In both the control and desmopressin parts of the study renal arginine vasopressin excretion fell in parallel with renal sodium excretion; it did not correlate with urine flow rate, urine osmolality, or osmolar excretion, but did correlate with sodium excretion (Figs 1 and 2). Clearly, renal arginine vasopressin excretion may not be a reliable index of arginine vasopressin secretion under conditions of altered sodium balance and excretion (compare lithium ${ }^{27}$ ).

In the whole animal, including humans, arginine vasopressin can be natriuretic, ${ }^{10}$ but at the single nephron level it stimulates sodium reabsorption in some species. ${ }^{28}$ The former has been attributed to water retention and volume expansion, ${ }^{28}$ and the latter to cyclic AMP stimulation in the medullary thick ascending limb and collecting duct. ${ }^{29}$ Natriuresis does occur during arginine vasopressin infusion in sodium and water restricted subjects. " An explanation for this apparent contradiction may lie in the different receptor types stimulated by arginine vasopressin: the Vl (vascular) receptor is found in

TABLE I Changes in plasma composition and salivary aldosterone concentration after dietary sodium restriction in ileostomy patients; day 3 (high sodium, HS) to day 4 (low sodium, LS); control and desmopressin (mean (SEM))

\begin{tabular}{|c|c|c|c|c|c|c|c|c|}
\hline Day & $\begin{array}{l}\text { Plasma } \\
\text { osmolality } \\
(\mathrm{mOsm} / \mathrm{kg})\end{array}$ & $\begin{array}{l}\text { Plasma Na } \\
\text { (mmolll) }\end{array}$ & $\begin{array}{l}\text { Plasma K } \\
(\mathrm{mmol} / \mathrm{l})\end{array}$ & $\begin{array}{l}\text { Plasma Ca } \\
(\mathrm{mmol} / \mathrm{l})\end{array}$ & $\begin{array}{l}\text { Plasma } \\
\text { phosphate } \\
\text { (mmolll) }\end{array}$ & $\begin{array}{l}\text { Total protein } \\
(\mathrm{g} / \mathrm{l})\end{array}$ & $\begin{array}{l}\text { Plasma renin activity } \\
(\mathrm{pg} / \mathrm{ml} / \mathrm{h}) \text { (geometric } \\
\text { mean }+95 \% \text { confidence } \\
\text { intervals) }\end{array}$ & $\begin{array}{l}\text { Salivary aldosterone } \dagger \\
(\text { pmol/l) (geometric } \\
\text { mean }+95 \% \text { confidence } \\
\text { intervals) }\end{array}$ \\
\hline \multirow{2}{*}{$\begin{array}{l}\text { Control: } \\
3 \text { (HS) } \\
4 \text { (LS) } \\
5(0800) \\
\text { Desmopressin: } \\
3 \text { (HS) } \\
4 \text { (LS) } \\
5(0800)\end{array}$} & $\begin{array}{l}292 \cdot 3(0 \cdot 8) \\
287 \cdot 8(0 \cdot 9)^{\star} \\
292 \cdot 4(1 \cdot 8)\end{array}$ & $\begin{array}{l}138 \cdot 7(0 \cdot 3) \\
137 \cdot 1(0 \cdot 5)^{\star} \\
136.9(0 \cdot 7)^{\star}\end{array}$ & $\begin{array}{l}3.97(0.06) \\
3.95(0.07) \\
3.93(0.10)\end{array}$ & $\begin{array}{l}2.56(0.02) \\
2.64(0.02)^{\star} \\
2.65(0.02)^{\star}\end{array}$ & $\begin{array}{l}1 \cdot 13(0.01) \\
1 \cdot 14(0.01) \\
1 \cdot 14(0.02)\end{array}$ & $\begin{array}{l}87 \cdot 0(0 \cdot 8) \\
90 \cdot 2(0 \cdot 9)^{\star} \\
92 \cdot 4(0 \cdot 7)^{\star}\end{array}$ & $\begin{array}{l}1560(1345 \text { to } 1808) \\
1767(1525 \text { to } 2049) \\
3955(3062 \text { to } 5108)^{\star}\end{array}$ & $\begin{array}{l}93 \cdot 3(69 \cdot 3 \text { to } 125 \cdot 6) \\
105 \cdot 0(76 \cdot 8 \text { to } 143 \cdot 5) \\
-\end{array}$ \\
\hline & $\begin{array}{l}289 \cdot 7(1 \cdot 0) \\
284 \cdot 3(1 \cdot 2)^{\star \star} \\
279 \cdot 2(3 \cdot 6)^{\star \star}\end{array}$ & $\begin{array}{l}139 \cdot 7(0 \cdot 5) \\
136 \cdot 4(0 \cdot 6)^{\star \star} \\
133 \cdot 6(1 \cdot 1)^{\star \star}\end{array}$ & $\begin{array}{l}4.05(0.09) \\
3.99(0.07) \\
3.70(0.06)\end{array}$ & $\begin{array}{l}- \\
- \\
-\end{array}$ & $\begin{array}{l}- \\
- \\
-\end{array}$ & $\begin{array}{l}83 \cdot 7(1 \cdot 3) \\
85 \cdot 8(1 \cdot 3) \\
84 \cdot 6(2 \cdot 7)\end{array}$ & $\begin{array}{l}1823(1378 \text { to } 2410) \\
2096(1585 \text { to } 2772) \\
3407(1983 \text { to } 5855)^{\star}\end{array}$ & $\begin{array}{l}63 \cdot 1(47 \cdot 8 \text { to } 83 \cdot 3) \\
107 \cdot 0(80 \cdot 6 \text { to } 142 \cdot 0) \\
143 \cdot 3(77 \cdot 0 \text { to } 266 \cdot 7)^{\star \star}\end{array}$ \\
\hline
\end{tabular}

${ }^{\star} \mathrm{p}<0.05$ and ${ }^{\star \star} \mathrm{p}<0.01$ compared with the corresponding value on day $3 .+$ Log-transformed variable. 
TABLE II Changes in ileal fluid, sodium, and potassium excretion rates after dietary sodium restriction in ileostomy patients; day 3 (high sodium, HS) to day 4 (low sodium, $L S)$; control and desmopressin (mean (SEM))

\begin{tabular}{|c|c|c|c|}
\hline & $\begin{array}{l}\text { Ileal flow rate } \\
(\mathrm{ml} / \mathrm{h})\end{array}$ & $\begin{array}{l}\text { Ileal sodium loss } \\
(\mathrm{mmol} / \mathrm{h})\end{array}$ & $\begin{array}{l}\text { Ileal potassium } \\
\text { loss }(\text { mmol/h })\end{array}$ \\
\hline \multirow{2}{*}{\multicolumn{4}{|c|}{$\begin{array}{l}\text { Control: } \\
3(\text { HS) } \\
4(\text { LS) } \\
\text { Desmopressin: }\end{array}$}} \\
\hline & & & \\
\hline $\begin{array}{l}3 \text { (HS) } \\
4 \text { (LS) }\end{array}$ & $\begin{array}{l}39 \cdot 8(3 \cdot 4) \\
38.9(7 \cdot 6)\end{array}$ & $\begin{array}{l}4.87(0.95) \\
5.08(1.98)\end{array}$ & $\begin{array}{l}0.33(0.05) \\
0.32(0.08)\end{array}$ \\
\hline
\end{tabular}

vascular smooth muscle and mediates the vasoconstrictor effect of arginine vasopressin; the V2 (antidiuretic) receptor is found in the kidney distal tubule and mediates increased water permeability. ${ }^{28-30}$ There is some evidence that V1 receptor stimulation can cause intrarenal release of prostaglandins $\left(\mathrm{PGE}_{2}\right)$, which are natriuretic and oppose the antidiuretic effect of arginine vasopressin..$^{29-32}$ This effect of prostaglandins may be directly on the tubule, inhibiting arginine vasopressin induced cAMP stimulation, or secondary to increased medullary blood flow and solute washout..$^{33}$ A similar negative feedback mechanism is seen with other pressor agents: angiotensin II and noradrenaline (increased in sodium depletion) also stimulate intrarenal PGE release, which counters their intrinsic effect, although the mechanism of antagonism is unclear (pharmacological or physiological). The net renal effect of prostaglandin release depends on the background concentration of such hormones, only becoming apparent when synthesis is inhibited - for example, by indomethacin. ${ }^{34}$ Salt depletion per se is associated with increased renal $\mathrm{PGE}_{2}$ synthesis. ${ }^{35}$ In our study the V2 receptor agonist desmopressin ${ }^{31}$ did not affect renal sodium excretion; however, there are reports that desmopressin may increase renal $\mathrm{PGE}_{2}$ production $^{36}$ (which could obscure any antinatriuretic effect), but not in humans. ${ }^{37}$ Nevertheless, it is still possible that $\mathrm{V} 1$, or a recently postulated $\mathrm{V}_{3}{ }^{29}$ receptor stimulation may lead to release of other local mediators, such as neuropeptides, ${ }^{38}$ resulting in actions distinct from V2 receptor stimulation.

Finally, despite early reports that the stimulatory effect of volume depletion on arginine vasopressin release can overcome the inhibitory effect of reduced plasma osmolality (Table I; weight $v$ osmolality), and later reports that hypovolaemia sensitises osmoregulation (reduced threshold), the relation is probably more complex, with one or other dominating under different conditions. In sodium depletion osmolality seems to be dominant. ${ }^{39}$

The site of renal sodium conservation is probably distal nephron, because phosphate excretion, a marker of proximal tubule reabsorption - for example, by peritubular physical factors such as oncotic pressure - did not fall. The early stimulus to sodium reabsorption is also uncertain: plasma renin activity (and by inference angiotensin II, which has a proximal tubule antinatriuretic effect) and salivary androsterone concentration did not increase appreciably (day 3 $v$ day 4 ) until after the initial decline in renal sodium excretion. ${ }^{12}$

Arginine vasopressin-like immunoreactivity is present in the rat jejunum ${ }^{40}$ and is thought to regulate the mucosal microcirculation. ${ }^{41}{ }^{42}$ There are reports of arginine vasopressin either inhibiting sodium and water reabsorption ${ }^{43}$ or having no effect $^{44}$; increased circulating concentrations have also been implicated as a cause of postoperative paralytic ileus. ${ }^{45}$ In our study desmopressin had no effect on ileal volume or composition, suggesting that any inhibitory effect of native arginine vasopressin may be secondary to its vasoconstrictive action or, like its $\mathrm{V} 1 / \mathrm{V} 3$ receptor renal effect, may be due to local release of other mediators such as prostanoids ${ }^{46}$ or neuropeptides. ${ }^{38}$

The phenomenon of 'low sodium' diuresis may be an important contributing factor to salt and water depletion in patients with ileostomies. While reversing the diuresis of sodium restriction, the V2 agonist desmopressin does not affect renal sodium excretion or ileal loss. It seems likely that the mechanism of the prompt decline in renal sodium excretion involves more than activation of the renin-angiotensin-aldosterone system alone.

We are very grateful to Charlotte Cocks and Liz Evans of the Department of Dietetics, St Mary's Hospital, for preparing the diets and Carol Hanson and Laura Watson for their technical help. This work was supported by the Wellcome Trust.

1 Kramer P. The effect of varying sodium loads on the ileal excreta of human ileostomized subjects. $\mathcal{F}$ Clin Invest 1966 45: $1710-8$.

2 Moss S, Gordon D, Forsling ML, et al. Water and electrolyte composition of urine and ileal fluid and its relationship to renin and aldosterone during dietary sodium deprivation in patients with ileostomies. Clin Sci 1981; 61: 407-15.

3 Carmichael DJS, Unwin RJ, Few JD, et al. Sodium depletion in ileostomy patients. Lancet 1986; ii: 364 .

4 Unwin RJ, Moss S, Peart WS, et al. Renal adaptation and gu hormone release during sodium restriction in ileostomized man. Clin Sci 1985; 69: 299-308

5 Share L, Claybaugh JR, Hatch FEJr et al. Effects of change in posture and of sodium depletion on plasma levels of vasopressin and renin in normal human subjects. $\mathcal{F}$ Clin Endocrinol Metab 1972; 35: 171-4.

6 Brennan LA, Malvin RL. Concentrations of antidiuretic hormone in plasma during human sodium restriction. Nephron 1977; 19: 284-7.

7 Baylis PH. Osmoregulation and control of vasopressin secretion in healthy humans. Am $\mathcal{F}$ Physiol 1987; 253: R671-8.

8 Schrier RW, Berl T, Anderson RJ. Osmotic and non-osmotic control of AVP release. Am F Physiol 1979; 236: F321-32.

9 Dixey JJ, Williams TDM, Lightman SL, et al. The effect of indomethacin on the renal response to AVP in man. Clin Sci 1986; 70: 409-16.

10 Leaf A, Bartter FC, Santos RF, et al. Evidence in man that urinary electrolyte loss induced by pitressin is a function of water retention. $\mathcal{F}$ Clin Invest 1953; 32: 868-78.

11 Drew PJT, Barnes JN, Holly JMP, et al. The effects of chronic infusion of AVP in salt restricted, water deprived man. Clin infusion of AVP in sat

12 Carmichael DJS, Sutters MS, Unwin RJ, et al. Time-course and relationship of the early changes in renal sodium excretion and aldosterone secretion during dietary sodium restriction in normal man. Clin Sci 1990; 78: 605-12.

13 Mathias CJ, Fosbraey P, daCosta DF, et al. The effect of desmopressin on nocturnal polyuria, overnight weight loss, and morning postural hypotension in patients with autonomic failure. $B M F$ 1986; 293 : 353-4

14 Sever PS, Peart WS, Davies IB, et al. Ethnic differences in blood pressure with observations on noradrenaline and renin: 2, a hospital hypertensive population. Clin Exp Hypertens 1979; 1: 745-60.

15 Few JD, Chaudry S, James VHT. The direct determination of aldosterone in human saliva. $\mathcal{F}$ Steroid Biochem 1984; 21 : 87 92.

16 Seckle JR, Williams TDM, Lyon CC, et al. Urinary vasopressin as a measure of sustained changes in vasopressin pressin as a measure of sustained changes
secretion. Clin Sci 1986; 71 (suppl 15): 14P.

17 Calam J, Dimaline R, Peart WS, et al. Effects of vasoactive intestinal polypeptide (VIP) on renal function in man f Physiol 1983; 345: 469-75.

18 Anderson RJ, Linas SL. Sodium depletion states. In: Brenner BM, Stein JH, eds. Sodium and water homeostasis. Edinburgh: Churchill Livingstone, 1978: 154-77.

19 Baker GP, Levitin H, Epstein FH. Sodium depletion and rena conservation of water. F Clin Invest 1961; 40: 867-73.

20 Cowley DAW, Skelton MM, Merrill DC, et al. Influence of daily sodium intake on vasopressin secretion and drinking in dogs. Am f Physiol 1983; 245: R860-72. 
21 Wietzman RE, Fisher DA, DiStefano JJ, et al. Episodic secretion of arginine vasopressin. Am f Physiol 1977; 233: E32-6.

22 Miller M, Moses AM. Radioimmunoassay of urinary antidiuretic hormone in man: response to water load and dehydration in normal subjects. $\mathcal{F}$ Clin Endocrinol 1972; 34: 537-45.

23 Tausch A, Stegner H, Leake RD, et al. Radioimmunoassay of arginine vasopressin in urine: development and application. arginine vasopressin in urine: development
$\mathcal{f}$ Clin Endocrinol Metab 1983; 57: 777-81.

24 Matsui KL, Share L, Wang BC, et al. Effects of changes in steady state plasma vasopressin levels on renal and urinary vasopressin clearance in the dog. Endocrinology 1983; 112 2107-13.

25 Robertson GL. The physiology of vasopressin excretion in man. [Abstract]. Clin Res 1972; 20: 778.

26 Pruszczynski W, Caillens H, Drieu L, et al. Renal excretion of antidiuretic hormone in healthy subjects and patients with renal failure. Clin Sci 1984; 67: 307-12.

27 Skott P, Bruun NE, Giese J, et al. What does lithium clearance measure? Clin Sci 1987; 73: 126-7.

28 Valtin H. Physiological effects of vasopressin on the kidney. In: Gash DM, Boer GJ, eds. Vasopressin. New York: Plenum, 1987: 369-87.

29 Lear S, Kelley VE. Arachidonic acid metabolism in rena disease. In: Halushka PV, Mais DE, eds. Eicosanoids in the cardiovascular and renal systems. Lancaster: MTP Press, 1988: $34-66$.

30 Chan WY, Hruby VJ. Natriuretic action of neurohypophysia peptides: effects of agonists and antagonists and the implication of natriuretic receptor. F Pharmacol Exp Ther 1988;246: $597-601$.

31 Sawyer WH, Manning M. Specificity of agonistic and antagonistic analogues of vasopressin. In: Robinson RR, ed. Proceedings of the ninth international congress of nephrology. New Yoedings of the ninth international congress

32 Bonvalet JP, Pradelles P, Farman N. Segmental synthesis and actions of prostaglandins along the nephron. Am $\mathcal{F}$ Physiol 1987; 253: F377-87.

33 Koeppen B. Mechanisms of segmental sodium and chloride reabsorption. In: Seldin DW, Giebisch G, eds. The regulation of sodium and chloride balance. New York: Raven Press, 1989 59-104.
34 Nadler SP, Brenner BM. Role of arachidonic acid metabolites in body fluid homeostasis. In: Brenner BM, Stein JH, eds. Body fuid homeostasis. Edinburgh: Churchill Livingstone, 1987: 101-129.

35 Oliver JA, Pinto J, Sciacca RR, et al. Increased renal secretion of norepinephrine and prostaglandin $E_{2}$ during sodium depletion in the dog. 7 Clin Invest 1980; 66: 748-56.

36 Craven PA, Verbalis JG, DeRubertis FR. Increased urinary excretion of $P G E$, during inappropriate antidiuresis induced excretion of $\mathrm{PGE}_{2}$ during inappropriate an

37 Walker RM, Brown RS, Stoff JS. Role of renal prostaglandins during antidiuresis and water diuresis in man. Kidney Int 1981; 21: 365-70.

38 Unwin RJ, Ganz MD, Sterzel RB. Brain-gut peptides, renal function and cell growth. Kidney Int 1990; 37 $1031-47$.

39 Weitzman RE. Factors regulating the secretion and metabolism of arginine vasopressin (antidiuretic hormone). In: Brenner BM, Stein JH, eds. Hormonal function and the kidney. Edinburgh: Churchill Livingstone, 1979: $146-68$.

40 Sanchez-Franco F, Cacicedo L, Vasallo JL, et al. Argininevasopressin immunoreactive material in the gastrointestinal vasopressin immunoreactive material
tract. Histochemistry 1986; 85: 419-22.

41 Holliger C, Radzyner M, Knoblauch M. Effects of glucagon, vasoactive intestinal peptide, and vasopressin on villous microcirculation and superior mesenteric artery blood flow of the rat. Gastroenterology 1983; 85: 1036-43.

42 Quillen EW, Granger DN, Taylor AE. Effects of arginine vasopressin on capillary filtration in the cat ileum. Gastroenterology 1987; 73: 1290-5.

43 Dennhardt R, Lingelbach B, Haberich FJ. Intestinal absorption under the influence of vasopressin: studies in unanaesthetised rats. Gut 1979; 20: 107-13.

44 Kosuba RB, Ivanov IuI. Effect of aldosterone, vasopressin and natriuretic factor on the process of absorption in the rat small natriuretic factor on the process of absorption in
intestine. Biull E ksp Biol Med 1977; 83: 704-7.

45 Mitchell A, Collin J. Vasopressin effects on the small intestine: a possible factor in paralytic ileus? Br $\mathcal{F}$ Surg $1985 ; 72: 462-5$

46 Bukhave K, Rask-Madsen J. Saturation kinetics applied to in vitro effects of low prostaglandin $E_{2}$ and $F_{2}$ concentrations on ion transport across human jejunal mucosa. Gastroenterology 1980; 78: 32-42. 